\title{
Changes in Concentrations of Tannins, Total Phenolics, Crude Protein, and In Vitro Digestibility of Browse due to Mastication and Insalivation by Cattle
}

\author{
E.A. BURRITT, J.C. MALECHEK, AND F.D. PROVENZA
}

\begin{abstract}
The feasibility of using esophageal extruan to monitor dietary tannin levels was studied using 4 shrub species (Purshia tridentata, Quercus gambelit, Cercocarpus montanus and Acer grandidentatwm). Browse samples were hand-harvested in late summer. Half of the sample for each species was fed to esophageally fistulated cattle, while the other half served as an unmasticated control. Extrusa and control samples were analyzed for total phenolics (Folin-Denis), tannin using 3 methods (vanillin-HCl, proanthocyanidins, and astringency), crude protein, and in vitro organic matter digeatibility (IVOMD). Tannin levels were reduced $10 \%$ to $60 \%$ in extrusa, depending on plant species and method of tannin analysis. Changes in the nutritional constituents of extrusa were limited but oak extrusa was higher in IVOMD than oak control samples. Tannins may have bound to plant or salivary proteins or to mucous membranes in the mouth during mastication and insallvation. Our results indicate that esophageal extrusa is not suitable for monitoring dietary tannin levels.
\end{abstract}

Key Words: tannins, shrubs, esophageal extrusa, mastication

Tannins are high molecular weight polyphenols that bind to proteins and carbohydrates. Tannins have been divided into 2 categories: hydrolyzable and condensed. Hydrolyzable tannins are esters of glucose and phenolic acid, whereas condensed tannins are polymers of condensed flavan-3-ol units (Hahn et al. 1984). They have been reported to adversely affect digestibility (Waterman et al. 1980, Buckley et al. 1983, Burns and Cope 1974), decrease palatability (Provenza and Malechek 1984, Cooper and OwenSmith 1985), and inhibit enzymatic (Goldstein and Swain 1965) and microbial (Henis et al. 1964) activity. Conversely, tannins may benefit ruminants by protecting protein from bacterial deamination (Driedger and Hatfield 1972) and preventing bloat (Jones and Lyttleton 1970). Tannins exist in a wide variety of plant species. In a survey by Bate-Smith and Metcalf (1957), approximately $80 \%$ of woody perennial dicots and $15 \%$ of annual and herbaceous perennial dicots contained tannins. Considering this information, further studies concerning tannins and their effect on grazing ungulates are necessary.

The nutritive value of diets selected by free-ranging livestock are frequently evaluated using forage material collected via esophageally fistulated animals (i.e., extrusa). While analyses of extrusa are reliable for determining dietary levels of crude protein, fiber, and digestibility (Cohen 1979, Smith et al. 1967), they are not adequate for assessing other dietary constituents, such as minerals (Scales et al. 1974) or monoterpenoids (White et al. 1982). Recently, Krysl et al. (1985) correlated total phenolics (FolinDenis) and tannin levels (vanillin-HCl) in extrusa from cattle with digestibility and intake variables. However, a preliminary study conducted by Provenza and Malechek (1984) indicated a 50\% reduction in blackbrush (Coleogyne ramosissima) tannin levels

\footnotetext{
Authors are research associate, department head, and assistant professor, respectively, Range Science Department, Utah State University, Logan 84322.

This research was funded in part by the United States Agency for International Development Title XIl Small Ruminants Collaborative Research Support Program under Grant No. AID/ DSAN/ XII-G-0049, in collaboration with Empresa Brasileira de Pesquisa Agropecuaria, Brazil.

This paper is published with the approval of the director, Utah Agr. Exp. Sta., Utah State Univ., Logan, as Journal Paper No. 3237

Manuscript accepted 16 March 1987.
}

due to mastication and passage through esophageal fistulae of goats. In addition, Mehansho et al. (1983) reported that rats on high-tannin diets produce proline-rich salivary proteins that have a high affinity for tannins. Therefore, the objective of this study was to determine the feasibility of using esophageal extrusa from cattle to monitor dietary levels of tannins, total phenolics, crude protein and IVOMD.

\section{Materials and Methods}

Four species of browse, mountain mahogany (Cercocarpus montanus), bitterbrush (Purshia tridentata), Gambel oak (Quercus gambeli), and bigtooth maple (Acer grandidentatum) were hand-harvested in mid-September, when tissues were no longer actively growing but prior to the first frost. Current season's twigs and leaves were collected from oak, bitterbrush, and mountain mahogany, while only leaves were collected from maple. Samples were divided into thirds and half of each subsample $(500 \mathrm{~g})$ was fed to 1 of 3 esophageally fistulated heifers, while the other half of each subsample served as an unmasticated control. Heifers were maintained on alfalfa hay. Upon collection, extrusa and control samples were frozen, freeze-dried, and ground. Samples were analyzed for crude protein $(\mathrm{N} \times 6.25)$ using the Kjeldahl nitrogen technique (Harris 1970) and in vitro organic matter digestibility (IVOMD) (Tilley and Terry 1963). Total phenolics were measured using the Folin-Denis assay (Martin and Martin 1982). Tannin concentrations were determined using 3 methods: vanillin- $\mathrm{HCl}$ (Price et al. 1978), proanthocyanidin (Bullard et al. 1981), and protein-precipitating phenolics (astringency) (Hagerman and Butler 1978).

Three separate tannin assays and a measure of total phenolics were utilized because there is no definitive method for measuring tannin concentrations (Bullard et al. 1981, Martin and Martin 1982). All 4 methods are frequently used and each measures a different chemical characteristic associated with tannins. The Folin-Denis assay (Martin and Martin 1982) measures phenolic acids, flavanoids, and tannins and is based on the reducing power of the phenolic hydroxyl groups (Hahn et al. 1984). It is neither a direct or indirect measure of tannin although results from this assay are often expressed in terms of tannic acid equivalents and frequently interpreted in this light (Martin and Martin 1982). The vanillin- $\mathrm{HCl}$ assay (Price et al. 1978) reacts with certain types of flavanoids; many are precursors to condensed tannin and do not precipitate proteins (Waterman et al. 1980). Results from this assay are expressed in catechin equivalents. Catechin is a tannin precursor that does not precipitate protein. The proanthocyanidin (Bullard et al. 1981) method measures condensed tannin but also measures nontannin monomeric flavanoids (Martin and Martin 1982). The standard used in this assay is a quebracho tannin, a commercially prepared tannin (Pilar River Plate Corp., Newark, New Jersey). Hagerman and Butler's (1978) procedure measures protein precipitating phenolics in term of tannic acid equivalents. The assay depends on a phenol measurement, and therefore depends not only on tannin content but also on tannin structure (Martin and Martin 1982).

The analyses of variance for comparing extrusa with control samples and for comparing ratios among plant species were factorials with 2 and 4 treatments, respectively. Animals $(n=3)$ were used 
Table 1. Tannin levels (mg of equivalents/g of organic matter) in control (C) and extrusa (E) samples from cattle consuming 4 browse species as estimated by 4 assays.

\begin{tabular}{|c|c|c|c|c|c|c|c|c|c|c|c|c|}
\hline \multirow[b]{2}{*}{ Plant species } & \multicolumn{3}{|c|}{ Vanillin } & \multicolumn{3}{|c|}{ Proanthocyanidins } & \multicolumn{3}{|c|}{ Astringency } & \multicolumn{3}{|c|}{ Folin-Denis } \\
\hline & C & $\mathbf{E}$ & $\mathrm{E}: \mathrm{C}$ & $\mathrm{C}$ & $\mathbf{E}$ & $\mathrm{E}: \mathrm{C}$ & $\mathbf{C}$ & $\mathbf{E}$ & $E: C$ & E & $\mathbf{C}$ & E:C \\
\hline & \multicolumn{3}{|c|}{$\mathrm{mg} \mathrm{CE} E^{1} / \mathrm{g}$} & \multicolumn{3}{|c|}{$\mathrm{mg} \mathrm{QTE}{ }^{2} / \mathrm{g}$} & \multicolumn{3}{|c|}{$m g \operatorname{TAE}^{3} / \mathrm{g}$} & \multicolumn{3}{|c|}{ mg TAE $/ g$} \\
\hline Oak & $91.2^{* 4}$ & 39.4 & $.43 \mathrm{a}^{5}$ & $200.3^{*}$ & 133.1 & $.67 \mathrm{a}$ & $30.0^{*}$ & 12.0 & $.40 \mathrm{a}$ & $118.9^{*}$ & 95.4 & $.80 \mathrm{a}$ \\
\hline Bitterbrush & $110.8 *$ & 71.2 & $.64 b$ & 293.0* & 240.8 & $.82 \mathrm{~b}$ & $23.9^{*}$ & 14.1 & $.59 b$ & $122.3^{*}$ & 103.2 & $.85 a$ \\
\hline Maple & $21.8^{*}$ & 15.2 & $.70 \mathrm{~b}$ & $62.9^{*}$ & 51.4 & $.82 \mathrm{~b}$ & $31.4^{*}$ & 19.9 & $.63 b$ & $170.4^{*}$ & 142.9 & $.84 a$ \\
\hline Mahogany & $118.2^{*}$ & 91.7 & $.78 b$ & $268.0^{*}$ & 220.7 & $.82 b$ & 13.4 & 11.0 & $.82 \mathrm{c}$ & 79.1 & 72.6 & $.92 \mathrm{a}$ \\
\hline
\end{tabular}

icatechin equivalents

'quebracho tannin equivalents

3 tannic acid equivalents

4*indicates tannin concentration of $E$ and $C$ are significantly different $(P>0.05)$

${ }^{5}$ Ratios within a column followed by the same letter are not significantly different $(P>0.05)$.

as the error term in both cases. Significant differences between means were detected at the 0.05 level using least significant difference.

\section{Results}

Estimated tannin levels were lower in extrusa samples than in the controls. This reduction was dependent on plant species as well as analytical procedure. Tannin levels in extrusa were reduced significantly for all tannin methods in oak, bitterbrush, and maple (Table 1). Reductions in mountain mahogany tannin concentrations were significant for the vanillin- $\mathrm{HCl}$ and proanthocyanidin assays, but not for the astringency and Folin-Denis assays. When using the astringency assay, the decline in tannin levels of oak extrusa was greater than the decline in either bitterbrush or maple tannin levels and the decline in tannin levels of these 2 species differed significantly from the decline in mountain mahogany tannin levels (Table 1). Similarly, the decline in tannin levels of oak extrusa was greater than the decline in tannin levels for the other 3 species when using the vanillin- $\mathrm{HCl}$ or proanthocyanidin assays. However, there were no significant differences between species with Folin-Denis assay.

Estimates of tannin levels varied greatly between analytical methods. Martin and Martin (1982) assayed 6 species of oak for tannin concentrations and found no correlation between tannin estimates using the Folin-Denis assay, the proanthocyanidin method, and Hagerman and Butler's astringency assay. In addition, Riecherdt et al. (1984) assayed various plant parts of mature and juvenile paper birch (Betula resinifera) for tannins and total phenolics using several different methods and found little agreement between tannin estimates.

Animal-to-animal variation was high for some plant species. For example, tannin levels in maple extrusa were reduced $22 \%$ for heifer $1,33 \%$ for heifer 2 , and $55 \%$ for heifer 3 when the astringency assay was used. Similarly, tannin levels in mountain mahogany declined $14 \%, 20 \%$, and $32 \%$ for heifers 1,2 , and 3 , respectively when using the vanillin $\mathrm{HCl}$ method. However, very little animalto-animal variation was observed for oak and bitterbrush extrusa.

Generally, dietary levels of crude protein or IVOMD (Table 2) were similar for control and extrusa samples but crude protein

Table 2. Crude protein concentrations (dry matter basis) and in vitro organic matter digestibility (IVOMD) of control (C) and extrusa (E) samples from cattle consuming 4 browse species.

\begin{tabular}{lccccc}
\hline \hline & \multicolumn{2}{c}{ IVOMD (\%) } & & \multicolumn{2}{c}{ Crude Protein (\%) } \\
\cline { 2 - 3 } \cline { 5 - 6 } Plant Species & $\mathrm{C}$ & $\mathrm{E}$ & & $\mathrm{C}$ & $\mathrm{E}$ \\
\hline Oak & $35.5^{* 1}$ & 39.9 & & 10.5 & 10.7 \\
Bitterbrush & 44.7 & 44.4 & & 8.1 & 8.3 \\
Maple & 58.5 & 60.6 & & $9.5 *$ & 10.2 \\
Mahogany & 40.4 & 41.6 & & 7.7 & 8.0 \\
\hline
\end{tabular}

"Indicates crude protein and IVOMD of E and $C$ a re significantly different $(P>0.05)$. content of maple extrusa was higher than that of control maple and digestibility of oak browse was greater in masticated than in control forage.

\section{Discussion}

Tannins may have complexed with some compound(s) during mastication, probably with plant proteins. Tannins have been reported to have a high affinity for proteins near a protein's isoelectric point (Hagerman and Butler 1978). The isoelectric point of a protein is the $\mathrm{pH}$ at which the charge on a protein is zero (Lehninger 1975). There are hundreds of enzymes within plant tissues with a range of isoelectric points, and many may have bound with tannins during mastication. Tannin-protein binding occurs immediately under certain conditions (Martin and Martin 1983) and could have occurred during mastication and insalivation. Tannins have also been reported to complex with plant polysaccharides and bacteria and fungal cell walls (Swain 1979), and therefore may have bound to plant polysaccharides in extrusa.

Whether or not tannins bind to mucoproteins in saliva is problematic. Rats (Mehansho et al. 1983) on high tannin diets produce proline-rich salivary proteins that bind preferentially to tannins. However, deer, sheep (Robbins et al. 1987), and hamsters (Mehansho 1985) do not increase production of these proteins when consuming high tannin diets. The isoelectric point of bovine salivary mucoprotein is 1.5 (Lyttleton 1964) while the $\mathrm{pH}$ of bovine saliva is about 8 (Emery et al. 1960), suggesting tannins will not precipitate bovine salivary proteins. Jones and Mangan (1977) reported that mucoprotein isolated from bovine saliva does not complex with tannin at $39^{\circ} \mathrm{C}$ and pH 6.4. Furthermore, Robbins et al. (1987) reported that proteins in bovine saliva do not have a high affinity for tannins. None of the studies above used saliva from cattle maintained on high-tannin diets and are therefore comparable to our results. If cattle on high-tannin diets did produce proline-rich salivary proteins, then tannin levels of extrusa from cattle consuming high tannin forages would be depressed to a greater extent than was demonstrated in this study. Finally, salivary mucoproteins are glycoproteins that contain numerous, potentially reactive carbohydrate moieties. Research suggests that the carbohydrate sidechains of glycoproteins may complex substantial amounts of tannin without precipitation of the protein (Strumeyer and Malin 1970) and therefore may interfere with tannin quantification. Some researchers (Strumeyer and Malin 1970, Goldstein and Swain 1963) have suggested that tannins may bind to mucous membranes in the mouth, but no specific research has been conducted in this area.

While the increase in crude protein content of maple extrusa compared with the control was statistically significant, we do not consider it of practical importance and attribute it to salivary contamination (Scales et al. 1974). The increase in IVOMD of oak extrusa may have been caused by tannins forming an irreversible complex with either salivary mucoproteins or with cells from the epithelial lining of the mouth. If irreversible complexes formed, 
less tannin would have been available to bind to plant constituents and therefore inhibit in vitro digestion (Buckley et al. 1983, Burns and Cope 1974). Regardless of what the tannin bound to during mastication, this complex did not significantly enhance or hinder in vitro digestion of the remaining plant species.

Using mathematical equations to correct tannin levels in extrusa would be possible only if little animal-to-animal variation existed and one was working with a single species of tannin-containing forage plants. Our study focused on individual plant species and does not indicate the effect mastication and insalivation would have on tannin levels of a mixed diet of tannin and nontannincontaining species. While tannin complexes might be solubilized with a detergent solution (Hagerman and Butler 1978, Goldstein and Swain 1965), the reversibility of many tannin complexes decreases with time (Jones and Mangan 1977). However, botanical analysis of extrusa could be performed to determine species composition (Samuel and Howard 1982), and hand-harvested samples for each species could then be analyzed for tannins and dietary tannin levels computed.

\section{Conclusions}

In general, tannin levels declined significantly in extrusa as compared with controls. The extent of this decline was dependent on plant species, tannin method and, in some cases, individual animals. Direct chemical analyses of esophageal extrusa to monitor dietary tannin levels would grossly underestimate dietary tannin levels.

\section{Literature Cited}

Bate-Smith, E.C., and C.R. Metealf. 1957. Luecoanthocyanins 3. The nature and systematic distribution of tannins in dicotyledonous plants. $J$. Linn. Soc. Botany 55:669.

Buckley, K.E., T.J. Devlin, and R.R. Marquardt. 1983. Factors affecting in vitro rumen digestion of faba bean cultivars (Vicia faba L.). Can. J. Anim. Sci. 63:89-96.

Bullard, R.W., J.O. York, S.R. Kilburn. 1981. Polyphenolic changes in ripening bird-resistant sorghums. J. Agr. Food Chem. 29:973-981.

Burns, J.C., and W.A. Cope. 1974. Nutritive value of crownvetch forage as influenced by structural constituents and phenolic and tannin compounds. Agron. J. 66:195-200.

Cohen, R.D.H. 1979. Factors influencing the estimation of the nutritive value of the diet selected by cattle fistulated at the oesophagus. J. Agr. Sci. 93:607-618.

Cooper, S.M., and N. Owen-Smith. 1985. Condensed tannins deter feeding by browsing ruminants in a South African savanna. Oecologia 67:142-146.

Driedger, A., and E.E. Hatrield. 1972. Influence of tannins on the nutritive value of soybean meal for ruminants. J. Anim. Sci. 34:465-468.

Emery, R.S., C.K. Smith, R.M. Grimes, C.F. Hufiman, and C.W. Duncan. 1960. Physical and chemical changes in bovine saliva and rumen liquid with different hay-grain rations. J. Dairy Sci. 43:76-80.

Goldstein, J.L., and T. Swain. 1963. Changes in tannins in ripening fruits. Phytochemistry 2:371-383.

Goldstein, J.L., and T. Swain. 1965. The inhibition of enzymes by tannins. Phytochemistry 4:185-192.

Hagerman, A.E., and L.G. Butler. 1978. Protein precipitation method for the quantitative determination of tannins. J. Agr. Food Chem. 26:809-812.

Hahn, D.H., L.W. Rooney, and C.F. Earp. 1984. Tannins and phenols of sorghum. Cer. Foods World 29:776-779.

Harris, L.E. 1970. Nutrition research techniques for domestic and wild animals (Vol. 1). L.E. Harris, Logan, Utah.
Henis, Y., H. Tagari, and R. Volcani. 1964. Effect of water extract of carob pods, tannic acid, and their derivatives on the morphology and growth of micro-organisms. Appl. Microbiol. 12:204-209.

Jones, W.T., and J.W. Lyttleton. 1971. Bloat in cattle. XXXIV. A survey of legume forages that do and do not produce bloat. N.Z. J. Agr. Res. 14:101-107.

Jones, W.T., and J.L. Mangan. 1977. Complexes of the condensed tannins of sainfoin (Onobrychis viciifolia Scop) with fraction I leaf protein and with submaxillary mucprotein, and their reversal by polyethylene glycol and pH. J. Sci. Food Agr. 28:126-136.

Krysl, L.J., R.E. Estell, M.L. Galyean, and F.T. McCollum. 1985. Relationship of total phenolics and condensed tannins to forage intake, digestion and botanical composition in cattle grazing blue grama rangeland. Proc. West. Sec. Amer. Soc. Anim. Sci. 36:314-318.

Lehninger, A.L. 1975. Biochemistry. Worth Publishers Inc., New York.

Lyttleton, J.W. 1964. Bovine salivary mucoprotein: An improved method of isolation. N.Z.J. Agr. Res. 7:228-237.

Martin, J.S., and M.M. Martin. 1982. Tannin assays in ecological studies: Lack of correlation between phenolics, proanthocyanidins and proteinprecipitating constituents in mature foliage of 6 oak species. Oecologia 54:205-211.

Martin, J.S., and M.M. Martin. 1983. Tannin assays in ecological studies: Precipitation of ribulose-1, 5-bisphosphate carboxylase/oxygenase by tannic acid, quebracho, and oak foliage extracts. J. Chem. Ecol. 9:285-294.

Mehansho, H., A. Hagerman, S. Clements, L. Butler, J. Rogler, and D.M. Carlson. 1983. Modulation of proline-rich protein biosynthesis in rat parotid glands by sorghums with high tannin levels. Proc. Nat. Acad. Sci. 80:3948-3952.

Mehansho, H., J. Rogler, L. Butler, and D.M. Carlson. 1985. An unusual growth inhibiting effect of tannins on hamsters. Fed. Proc. 44:1860.

Price, M.L., S. Van Scoyoc, and L.G. Butler. 1978. A critical evaluation of the vanillin reaction as an assay for tannin in sorghum grain. J. Agr. Food Chem. 26:1214-1218.

Provenza, F.D., and J.C. Malechek. 1984. Diet selection by domestic goats in relation to blackbrush twig chemistry. J. Appl. Ecol. 21:831-841.

Reichardt, P.B., J.P. Bryant, T.P. Clausen, and G.D. Wieland. 1984. Defense of winter-dormant Alaska paper birch against snowshoe hares. Oecologia 65:58-69.

Robbins, C.T., S. Mole, A.E. Hagerman, and T.A. Hanley, 1987. Role of tannins in defending plants against ruminants: Reduction in dry matter digestion? Submitted to Ecology.

Samuels, M.J., and G.S. Howard. 1982. Botanical composition of summer cattle diets on the Wyoming high plains. J. Range Manage. 35:305-308.

Scales, G.H., C.L.Streeter, A.H. Denham, and G.M. Ward. 1974. Effect of mastication, salivary contamination and leaching on the chemical composition of forage samples collected via esophageal fistulae. J. Anim. Sci. 38:1278-1283.

Smith, T.M., A.L. Lesperance, and V.R. Bohman. 1967. Drying methods related to changes in chemical composition. Proc. West. Sec. Amer. Soc. Anim. Sci. 18:285-289.

Strumeyer, D.H., and M.J. Malin. 1970. Resistance of extracellular yeast invertase and other glycoproteins to denaturation by tannins. Biochem. J. 118:899-900.

Swain, T. 1979. Tannins and lignins. P. 657-682. In: G.A. Rosenthal and D.H. Janzen, eds. Herbivores: Their interaction with secondary plant metabolites. Academic Press, New York.

Tilley, J.M.A., and R.A. Terry. 1963. A two-stage technique for the in vitro digestion of forage crops. J. British Grassl. Soc. 18:104-111.

Waterman, P.G., C.N. Mbi, D.B. McKey, and J.S. Gartlan. 1980. African rainforest vegetation and rumen microbes: Phenolic compounds and nutrients as correlates of digestibility. Oecologia 47:22-33.

White, S.M., B.L. Welch, and J.T. Flinders. 1982. Monoterpenoid content of pygmy rabbit ingesta. J. Range Manage. 35:107-109. 